\title{
EFFECT OF KAPALBHATI PRANAYAMA ON WAIST AND HIP CIRCUMFERENCE
}

Dinkar Kekan, Shriniwas Kashalikar

1. Assistant Professor. Department of Physiology, SRTR Govt. Medical College Ambajogai.

2. Ex. Professor. Department of Physiology, Seth G. S. Medical College Parel, Mumbai.

\section{CORRESPONDING AUTHOR:}

Dr. Dinkar Kekan, 1-Sindhudurga, Class 2 Quarters,

SRTR Government Medical College,

Ambajogai District, Beed, Maharashtra- 431517.

E-mail: dinkarkekan@gmail.com

Ph: 00919579408463.

ABSTRACT: CONTEXT (BACKGROUND) AND AIMS: Rapid industrialization, environmental pollution, overcrowding, sedentary lifestyle and various stress factors are responsible for the deterioration of the physical health of a person. Also, prevalence of obesity in developing countries is believed to be on the rise. This requires special and specific techniques to transcend the limits of our physical and mental abilities experienced in everyday life. Hence, in the present study beneficial effect of Kapalbhati pranayama on waist circumference and hip circumference was studied in overweight individuals. METHODS AND MATERIALS: This study was conducted in a well-known tertiary hospital in Mumbai after the institutional ethical clearance and written consent from each participant. A total of 60 overweight resident doctors were recruited in this study. The participants were divided into study and control groups, each group containing 30 subjects of both sexes. The study group was asked to perform Kapalbhati pranayama. The duration of the study was eight weeks. Waist circumference and hip circumference were assessed in both the groups. STATISTICAL ANALYSIS: Paired t- test was applied for statistical analysis and $\mathrm{p}$ value $<0.05$ was considered the level of significance. RESULTS AND CONCLUSION: In study group, waist circumference and hip circumference decreased significantly as compared to that of control group. This shows that Kapalbhati pranayama has reducing impact on waist circumference and hip circumference in overweight individuals. The neuroendocrine and autonomic nervous system mechanisms might be involved in the effects of Kapalbhati pranayama, which need further study.

KEY WORDS: Kapalbhati pranayama, Waist circumference, Hip circumference

INTRODUCTION: Modern man is the victim of stress and stress related disorders which threaten to disrupt life totally. In modern life, due to rapid and vast industrialization and tremendous population growth, there is an overcrowding. In this era of competition, human beings are unable to draw time for physical exercise and for their physical health. Along with this sedentary lifestyle may be responsible for oveweightness and obesity.

Breath is the key to the mystery of life, says Lama Angarika Govinda. A human lifetime is measured from the first to the last breath. The process of life depends on how we breathe. Breathing is not only an instinctive reflex to satisfy the need of the body for oxygen but it has been considered that consciously controlled breathing can be used as a technique for enhancing mental and physical powers ${ }^{1}$. Special and specific techniques called pranayama have been 
evolved in yoga to transcend the limits of our physical and mental abilities experienced in our everyday life.

With increased awareness and interest in health and natural remedies, yogic techniques including pranayama are gaining importance and becoming increasingly acceptable to the scientific society ${ }^{2}$. Kapalbhati is a pranayama which is made up of two words 'kapal' in Sanskrit means forehead and 'bhati' means shining. Kapalbhati is a fast, rhythmic breathing using abdominal muscles. Pranayama has been shown to alter autonomic activity ${ }^{2}$. Prevalence of obesity in developing countries is believed to be on the rise ${ }^{3}$. Generalized obesity measured by body mass index (BMI) is one of the major causes of ill health in the society. However, abdominal obesity, which is closely associated with intraabdominal fat and measured either by waist circumference or waist-to-hip ratio, predicts subsequent coronary artery disease. Obesity is associated with the development of some of the most prevalent diseases of modern society, such as Type-II Diabetes Mellitus, hypertension, coronary artery disease, certain forms of cancer, arthritis, renal failure and gall bladder disease, and is associated with high morbidity and mortality ${ }^{3}$. Various other measures to reduce weight like dieting, hydrotherapy, steam bath, pharmacological therapy, surgical therapy, etc. are in use with variable results. In the present study, we made an attempt to find out any beneficial effects of kapalbhati pranayama on waist circumference and hip circumference in overweight young adults.

MATERIALS AND METHODS: This study was conducted in a well-known tertiary hospital in Mumbai after the institutional ethical clearance. The participants of the study were the overweight resident doctors of age group 24 to 28 years of both sexes. Informed and written consent was taken from all the participants. The duration of the study was eight weeks. The resident doctors having BMI between 25 and 29.9, who do not have any acute illness, having normal cardio respiratory function and those who had not undergone any major surgery were included in this study. Those participants who were doing any other physical exercises, having cardio respiratory problems, acute illness, and those who had undergone any major surgery were excluded from this study.

The recruited participants were divided into study group and control group, each containing 30 individuals of both sexes. Body weight, height, BMI, waist circumference and hip circumference was assessed from all participants. Weighing scale for measuring weight, standiometer for measuring height and measuring tape for measuring circumferences were used in the present study. Each individual from the study group was explained about the procedure of Kapalbhati in detail and sufficient trials were given for proper understanding. Kapalbhati was practiced by the subjects of study group for a period of 8 weeks regularly, Monday through Saturday under our direct supervision. At the end of 8 weeks parameters of the study were reassessed in both the study and control groups.

PROCEDURE OF KAPALBHATI PRANAYAMA: Kapalbhati should be practiced on empty stomach. Sit in comfortable crossed leg position or in any comfortable position with back straight, hands resting on knees. Kapalbhati involves abdominal muscle contractions with forceful exhalation and natural inhalation. Exhalation and inhalation together constitute one stroke. One can begin with 15 such strokes. After completing such 15 strokes inhale and exhale deeply and take a rest pause of about 15 to 20 seconds. While performing Kapalbhati, body should be steady. There should be no movement of head, shoulders, facial muscles, back and legs. Excess force and jerk should be avoided. 
This procedure was practiced for 15 minutes daily.

Statistical analysis: Paired t-test was used to find out the statistical significance of the results. The $p$-value $<0.05$ was considered the level of significance.

RESULTS: Table-1: Waist circumference in control group at the beginning and at the end of 8 weeks and in study group before and after Kapalbhati. Values are expressed as Mean \pm Standard Deviation. $\mathrm{N}=30$ in each group.

\begin{tabular}{|c|c|c|c|c|}
\hline & \multicolumn{2}{|c|}{ Control group } & \multicolumn{2}{|c|}{ Study group } \\
\hline & $\begin{array}{l}\text { Beginning } \\
\text { experiment }\end{array}$ & $\begin{array}{ll}\text { After } & 8 \\
\text { weeks } & \end{array}$ & $\begin{array}{l}\text { Beginning } \\
\text { experiment }\end{array}$ & $\begin{array}{lr}\text { After } \quad 8 \\
\text { weeks }\end{array}$ \\
\hline $\begin{array}{l}\text { Waist Circumference } \\
\text { (cm) }\end{array}$ & $85.11 \pm 4.11$ & $\begin{array}{ll}85.06 \quad \pm \\
4.28\end{array}$ & $85.89 \pm 5.41$ & $\begin{array}{ll}82.74 \quad \pm \\
4.84\end{array}$ \\
\hline p-value & \multicolumn{2}{|c|}{$>0.05$ (Nonsignificant) } & \multicolumn{2}{|c|}{$<0.01$ (Highly Significant) } \\
\hline
\end{tabular}

Waist Circumference: The waist circumference in the subjects from study group was found to be significantly decreased ( $p$ value $<0.1$ ) when compared before and after Kapalbhati. Whereas, the change in waist circumference was not significant in the subjects from control group ( $p$ value $>0.05$ ). This indicates that there was a significant decrease in waist circumference after Kapalbhati in subjects in study group as compared to that of control group.

Table-2: Hip circumference in control group at the beginning and at the end of 8 weeks and in study group before and after Kapalbhati. Values are expressed as Mean \pm Standard Deviation. $\mathrm{N}=30$ in each group.

\begin{tabular}{|c|c|c|c|c|}
\hline & \multicolumn{2}{|c|}{ Control group } & \multicolumn{2}{|c|}{ Study group } \\
\hline & $\begin{array}{ll}\text { Beginning } \\
\text { experiment }\end{array}$ & $\begin{array}{lr}\text { After } & 8 \\
\text { weeks } & \end{array}$ & $\begin{array}{l}\text { Beginning } \\
\text { experiment }\end{array}$ & $\begin{array}{l}\text { After } \quad \varepsilon \\
\text { weeks }\end{array}$ \\
\hline $\begin{array}{ll}\text { Hip } & \text { Circumference } \\
(\mathrm{cm}) & \end{array}$ & $97.19 \pm 2.65$ & $\begin{array}{ll}97.16 \quad \pm \\
2.67\end{array}$ & $97.94 \pm 2.33$ & $\begin{array}{l}95.67 \\
2.57\end{array}$ \\
\hline p-value & \multicolumn{2}{|c|}{$>0.05$ (Nonsignificant) } & \multicolumn{2}{|c|}{$<0.01$ (Highly Significant) } \\
\hline
\end{tabular}

HIP CIRCUMFERENCE: The hip circumference in the subjects from study group was found to be significantly decreased ( $p$ value $<0.1$ ) when compared before and after Kapalbhati. Whereas, the change in hip circumference was not significant in the subjects from control group ( $p$ value $>0.05$ ). This indicates that there was a significant decrease in hip circumference after Kapalbhati in subjects in study group as compared to that of control group.

DISCUSSION: Patanjali, first proponent of yoga, described pranayama as the gradual unforced cessation of breathing. The ancient science of yoga makes use of voluntary regulation of the breathing to make respiration rhythmic and to calm the mind to reach the ultimate goal ${ }^{4}$. This 
practice of pranayama is an art of controlling the breath. A practitioner of pranayama not only tries to breath but at the same time tries to keep his attention on the act of breathing, leading to concentration. This act of concentration removes his attention from worldly worries and destress him.

Kapalbhati pranayama involves abdominal muscle contractions with forceful exhalation and natural inhalation. It is a form of abdomino-respiratory-autonomic exercise. Due to this, respiratory, abdominal and gastrointestinal receptors get stimulated. Also, afferents, centers in brain-stem and cortex and, efferents and effectors get stimulated. This leads to synchronous stimulation of autonomic nervous system, hypothalamus, pineal gland and other associated brain structures. Because of this there is synchronous increase in autonomic nervous system, pineal gland, hypothalamus and other central nervous system discharge to all parts of the body including endocrine and metabolic processes. This is responsible for the effect of Kapalbhati on fat metabolism. This causes increase in basal metabolic rate, and because of this there is increase in calories consumption and decrease in fat deposition and so reduction in weight.

The pattern of body fat distribution is recognized as an important predictor of the health risks of obesity. Individuals with more fat on the trunk, especially abdominal fat, are at increased risk of obesity related health problems compared with individuals who are equally fat, but have more of their fat on extremities.

Waist-to-hip ratio or waist circumference alone has been used as a simple method for determining body fat pattern. The BMI is used to assess weight relative to height ${ }^{5}$. A high BMI links to an increase in risk of death from causes like hypertension, cardiovascular disease, dyslipidaemia, diabetes mellitus, sleep apnoea, osteoarthritis and female infertility ${ }^{6}$. Waist circumference coupled with BMI predicts health risk better than does BMI alone. Indians have high percentage of body fat at low BMI7.

In present study, waist circumference and hip circumference decreased significantly as compared to the control group. Decrease in body weight causes change in body fat distribution ${ }^{8}$, 9. Mauro Zamboni et al reported that weight loss is associated with changes in regional fat distribution. In premenopausal women weight loss correlates more closely with the amount of subcutaneous than visceral fat ${ }^{10}$. So, fat redistribution after weight loss might be the cause for decrease in the waist circumference and hip circumference in present study. The review on yoga showed that yoga had beneficial effect on body weight, blood pressure, blood glucose level and cholesterol level ${ }^{11}$. Nirmala N. Nayak reported that various yogasanas including Kapalbhati seem to have a positive effect in reducing obesity ${ }^{12}$. Swami Ramdev mentioned that Kapalbhati is helpful in reducing obesity ${ }^{13}$. In a study by Ajay Singh Ruhal et al (2010) it is reported that practice of Kapalbhati decreases lean body mass and body fat percentage and increases basal metabolic rate. The neuroendocrine ${ }^{14}$ and autonomic nervous system ${ }^{15}$ mechanisms might be involved in the effects of Kapalbhati pranayama.

CONCLUSION: From this study, it is concluded that Waist Circumference and Hip Circumference show a decline after practicing Kapalbhati pranayama.

LIMITATIONS OF THE STUDY: This study was done in overweight individuals; we had not studied these parameters in normal individuals. 


\section{REFERENCES:}

1. Gharote M L: Pranayama-the science of breath theory and guidelines for practice 2003; $1^{\text {st }}$ edition Pune. Pg-9.

2. N.K. Subbalakshmi, S.K. Saxena, Urmimala, and Urban J.A. D'Souza. Immediate effect of Nadi-shodhan pranayama on some selected parameters of cardiovascular, pulmonary, and higher functions of brain. Thai journal of physiological sciences. Vol. 18(2) 2005:1016.

3. Dhudmal VB. Effect of short term exercise on abdominal obesity and blood pressure. Milestone. July 2005; Vol 4(3):21-24.

4. Sri Paramhansa Yogananda. The immortal dialogue between soul and spirit. A new translation and commentary, chapter IV verse 29; 2002:496-507.

5. Gary J. Balady, Kathy A. Berra, Lawrence A. Golding, et al. Physical fitness testing and Interpretation. In: ACSM'S guidelines for exercise testing and prescription. American College of Sports Medicine; $6^{\text {th }}$ ed. Lippincot Williams and Wilkins Publication. 2000:5790.

6. WHO expert consultation. Appropriate body mass index for Asian populations and its implications for policy and interventional strategies. Lancet 2004; 363:157-63.

7. Deurenberg-Yap M, Schmidt G, van Staveren WA, Deurenberg P. The paradox of low body mass index and high body fat percentage among Chinese, Malays and Indians in Singapore. Int Obes Relat Metab Disord. 2000 Aug; 24(8):1011-7.

8. Francis E Johnston, Thomas A Wadden, Albert J Stunkard, Manual Pefla, Jack Wang, Richard N Pierson, and Theodore B Van Itallie. Body fat deposition in adult obese women. I Patterns of fat distribution ${ }^{1-3}$. Am J Clin Nutr 1988; 47:225-8.

9. Thomas A Wadden, Albert J Stunkard, Francis E Johnston, Jack Wang, et al. Body fat deposition in adult obese women. II Changes in fat distribution accompanying weight reduction ${ }^{1-3}$. Am J Clin Nutr 1988; 47:229-34.

10. Mauro Zamboni, Fabio Armellini, Emanuela Turcato, et al. Effect of weight loss on regional body fat distribution in premenopausal women ${ }^{1,2}$. Am J Clin Nutr 1993; 58:2934.

11. Yang K. A review of Yoga Programs for leading risk factors of Chronic Diseases. Evidence Based Alt Medicine 2007; 4(4):487-491.

12. Nirmala N. Nayak, Kamala Shankar. Yoga: a therapeutic approach. Phys Med Rehabil Clin N Am 15 (2004): 783 - 798.

13. Swami Ramdev. Seven Kinds of Pranayama. In: Pranayama- Its Philosophy and Practice. Divya Prakashan, Haridwar. May 2005: 28-29.

14. Faye Martins, 2011. Yoga Training: Bhastrika and Kapalbhati pranayama[online]. Attleboro, USA: Aurawellness Centre - Publication division. Available at: www.aurawellnesscenter.com [Assessed on 12/3/2013].

15. Raghuraj P, Ramakrishna AG, Nagendra HR. Effect of two related yogic breathing techniques on heart rate variability. Indian J Physiol Pharmacol 1998;42(4)467-472. 